University of Nebraska - Lincoln

DigitalCommons@University of Nebraska - Lincoln

Publications from USDA-ARS / UNL Faculty

U.S. Department of Agriculture: Agricultural

Research Service, Lincoln, Nebraska

November 1989

\title{
Soil Disturbance-Residue Management Effect on Winter Wheat Growth and Yield
}

Wallace Wilhelm

University of Nebraska-Lincoln, wwilhelm1@unl.edu

H. Bouzerzour

University of Nebraska-Lincoln

J. F. Power

University of Nebraska-Lincoln

Follow this and additional works at: https://digitalcommons.unl.edu/usdaarsfacpub

Part of the Agricultural Science Commons

Wilhelm, Wallace; Bouzerzour, H.; and Power, J. F., "Soil Disturbance-Residue Management Effect on Winter Wheat Growth and Yield" (1989). Publications from USDA-ARS / UNL Faculty. 119.

https://digitalcommons.unl.edu/usdaarsfacpub/119

This Article is brought to you for free and open access by the U.S. Department of Agriculture: Agricultural Research Service, Lincoln, Nebraska at DigitalCommons@University of Nebraska - Lincoln. It has been accepted for inclusion in Publications from USDA-ARS / UNL Faculty by an authorized administrator of DigitalCommons@University of Nebraska - Lincoln. 


\title{
Soil Disturbance-Residue Management Effect on Winter Wheat Growth and Yield
}

\author{
W. W. Wilhelm, ${ }^{*}$ H. Bouzerzour, and J. F. Power
}

\begin{abstract}
The need to reduce soil erosion, maximize soil water conservation, and optimize grain production in dryland cropping systems in the Central Great Plains has culminated in development of nontilled fallow systems. These systems have greatly reduced the degree of soil disturbance, and the amount and degree of residue incorporation. The objectives of this study were to evaluate the influence of soil disturbance and residue management on soil temperature, soil water, and winter wheat (Triticum aestivum L.) growth. Two field studies were established in 1981 and 1982 on an Alliance silt loam (Fine-silty, mixed, mesic Aridic Argiustoll) with treatments consisting of various degrees of soil disturbance (moldboard plow, tandem disk, and no tillage), residue incorporation (on the soil surface or incorporated), and amount of residue applied (0.0, 0.5, and 1.0 of that produced by the previous crop). Decreased soil disturbance (tillage) and increased residue application decreased maximum, and increased minimum, soil temperatures. In all tillage treatments, soil water content showed a significant positive linear relationship to residue application rate. Grain yield was similar for all treatment factors, except tillage within the $1983-1984$ season when tilled (3.48 $\mathrm{Mg} \mathrm{ha}^{-1}$ ) treatments produced more grain than the nontilled (3.20 $\mathrm{Mg} \mathrm{ha}^{-1}$ ) treatment. Early development and growth of winter wheat was slowed by the presence of residues (surface or incorporated) or the absence of tillage. However, by completion of heading, phenology and yield were similar for all treatments. Cooler soil temperatures slowed development and growth during those stages when the meristem temperature was influenced most by soil temperature. However, after jointing, when air temperature and photoperiod were controlling development and growth, differences among treatments disappeared. Interaction of wheat development with soil temperature, air temperature, and daylength may contribute to the crop's inability to consistently capitalize, in terms of grain yield, on the greater amount of water stored in nontilled and mulched systems.
\end{abstract}

W.W. Wilhelm and J.F. Power, Agric. Res. Serv., USDA, Keim Hall, East Campus, and $H$. Bouzerzour, Dep. of Agronomy, Univ. of Nebraska-Lincoln, Lincoln NE 68583. Contribution from USDAARS in cooperation with the Agric. Res. Div., Univ. of NebraskaLincoln, Lincoln NE. Published as Paper no. 8610 Journal Series, Agric. Res. Div. Received 11 April 1988. *Corresponding author. Published in Agron. J. 81:581-588 (1989).
QOIL EROSION and drought are among the major $\checkmark$ problems associated with grain production in the Central Great Plains. The need to reduce soil erosion and to maximize soil water conservation for optimum grain production culminated in the development of nontilled fallow systems (Duley, 1960; Fenster and Peterson, 1979; McCalla and Army, 1964). These systems of wheat production have become increasingly important in the Great Plains since the 1950s. Tillage practice effects on soil temperature, soil water, and crop growth have been widely studied (Adams, 1965, 1966; Adams et al., 1976; Allmaras et al., 1964; Army et al., 1961; Black, 1970; Burns et al., 1971; Ciha, 1982).

Reduced soil temperatures in mulched versus nonmulched soil, particularly during the time of the season when soils are warming and canopy cover is not established, have been reported frequently (Allmaras et al., 1964; Anderson and Russell, 1964; Burrows and Larson, 1962; Greb, 1966; Hillel et al., 1975). Anderson and Russell (1964) found that each $1.1 \mathrm{Mg} \mathrm{ha}^{-1}$ of straw mulch depressed morning temperature in the $100-$ and $200-\mathrm{mm}$ soil depth an average of $3^{\circ} \mathrm{C}$ during early spring, compared with bare soil. Crop growth is usually depressed under nontilled conditions in early spring (Allmaras et al., 1964; Anderson and Russell, 1964; Burrows and Larson, 1962). This may be caused by the influence of surface residues on soil temperature.

Soil water content is greater in mulched than in bare soils as a result of reduced evaporation (Adams et al., 1976; Anderson and Russell, 1964; Army et al., 1961; Burns et al., 1971; Hillel et al., 1975; Papendick et al., 1973). Mulches can reduce evaporation via one or more of following mechanisms: (i) reducing soil temperature, (ii) impeding vapor diffusion, (iii) acting as periodic focal points for temporary vapor condensation and absorption into mulch tissue, and (iv) reducing wind velocity at the soil interface (Greb, 1966). 
Table 1. Analysis of variance outline and explanation of single-degree-of-freedom comparisons used to evaluate data.

\begin{tabular}{|c|c|c|}
\hline Source of variation & df & Explanation \\
\hline Total & 51 & \\
\hline Blocks & 3 & \\
\hline Error & 36 & \\
\hline Treatments & 12 & \\
\hline Nontilled vs. tilled & 1 & $\begin{array}{l}\text { Test effect of nontilled (no tillage) vs. tilled soil (plow and disk), means averaged over residue } \\
\text { rates. }\end{array}$ \\
\hline Within nontilled & 2 & \\
\hline residue linear & 1 & Test effect of surface residue (on) in nontilled soil (no tillage); 0.0 residue vs. 1.0 residue. \\
\hline residue quadratic & 1 & Test effect of surface residue (on) in nontilled soil (no tillage); 0.5 residue vs. 0.0 and 1.0 residue. \\
\hline Within tilled & 9 & \\
\hline disk vs. plow & 1 & Test of disk vs. plow, means averaged over residue rates and placements. \\
\hline in vs. on & 1 & $\begin{array}{l}\text { Test effect of residue placement, incorporated vs. surface, in tilled soil; means averaged over disk } \\
\text { and plow. }\end{array}$ \\
\hline residue linear & 1 & $\begin{array}{l}\text { Test effect of surface residue (on) in tilled soil (average of disk and plow); } 0.0 \text { residue vs. } 1.0 \text { resi- } \\
\text { due. }\end{array}$ \\
\hline residue quadratic & 1 & $\begin{array}{l}\text { Test effect of surface residue (on) in tilled soil (average of disk and plow); } 0.5 \text { residue vs. } 0.0 \text { and } \\
1.0 \text { residue. }\end{array}$ \\
\hline disk vs. plow $X$ in vs. on & 1 & Test interaction of disk and plow by residue incorporation vs. surface application. \\
\hline disk vs. plow $\times$ residue linear & 1 & Test interaction between plow and disk by surface residue linear. \\
\hline disk vs. plow $\times$ residue quadratic & 1 & Test interaction between plow and disk by surface residue quadratic \\
\hline in vs. on $\times$ residue linear & 1 & Test interaction between incorporated vs. surface residue by residue linear \\
\hline in vs. on $\times$ residue quadratic & i & Test interaction between incorporated vs. surface residue by residue quadratic. \\
\hline
\end{tabular}

Considerable variation exists in the comparison of grain yield among tillage systems (Anderson and Russell, 1964; Ciha, 1982; Ellis et al., 1979; Fenster and Peterson, 1979). This may be a result of variation in the soil environment associated with the tillage systems studied and the interaction of the crop with that environment and seasonal weather fluctuation.

The transition from conventional to nontilled fallow has involved changes in two major factors: (i) degree of soil disturbance, and (ii) amount and degree of residue incorporation. The objectives of this study were to evaluate the influences of soil disturbance and residue management on soil temperature, soil water content, and winter wheat growth.

\section{MATERIALS AND METHODS}

Two experiments (one fallow during odd-numbered years and the crop harvested during even-numbered years, the other fallow during even-numbered years and harvested during odd-numbered years) were established at the University of Nebraska High Plains Agricultural Laboratory near Sidney, NE, on an Alliance silt loam in 1981 and 1982. Both experiments were designed as randomized, complete blocks with four replications. The $4.3 \times 12.2 \mathrm{~m}$ experimental units were arranged as an incomplete factorial. Treatment factors and levels were the same on both experiments; however, different randomization schemes were used to assign treatments to experimental units in the two experiments.

Treatments consisted of various degrees of soil disturbance (moldboard plow [ $100 \mathrm{~mm}]$, tandem disk [100 $\mathrm{mm}$, and no tillage), residue incorporation (incorporated [in] into soil or on [on] the soil surface), and amount of residue applied $(0.0,0.5$, and 1.0 of that produced by the previous crop). During April of the fallow year, amount of residue left in the field was determined in each plot by clipping and raking all aboveground material from a $2.2 \mathrm{~m}^{2}$ area. Residues collected were oven dried to a constant weight at $60^{\circ} \mathrm{C}$. Quantities of residue returned to all treatments were based on the average residue collected from all 1.0 treatments within each replication.

All residues were removed from the experimental units. Amount of straw to be returned was weighed and distributed uniformly on the appropriate plots, either before tillage (incorporated [in] treatments) or after tillage (surface [on] treatments). Residue application rate for the 1.0 treatments were $5.0,8.0,8.3$, and $3.56 \mathrm{Mg} \mathrm{ha}^{-1}$ for the $1981-1982,1982-$ $1983,1983-1984$, and 1985-1986 seasons, respectively. No
Table 2. Monthly and yearly total precipitation for Sidney, NE during 1981-1982, 1982-1983, 1983-1984, 1985-1986 cropping seasons, and normal monthly and seasonal totals.

\begin{tabular}{lrrrrr}
\hline & \multicolumn{5}{c}{ Cropping season } \\
\cline { 2 - 6 } Month & $1981-1982$ & $1982-1983$ & $1983-1984$ & $1985-1986$ & Normal \\
\hline & \multicolumn{5}{c}{ 1983 } \\
\cline { 2 - 6 } September & 9 & 26 & 7 & 67 & 27 \\
October & 44 & 7 & 14 & 9 & 21 \\
November & 5 & 15 & 35 & 15 & 12 \\
December & 0 & 4 & 3 & 2 & 9 \\
January & 1 & 0 & 1 & 0 & 8 \\
February & 1 & 0 & 13 & 9 & 8 \\
March & 11 & 39 & 19 & 13 & 23 \\
April & 11 & 29 & 39 & 9 & 42 \\
May & 70 & 59 & 39 & 60 & 77 \\
June & 108 & 108 & 29 & 138 & 78 \\
July & 115 & 51 & 35 & 49 & 68 \\
August & 34 & 42 & 52 & 44 & 46 \\
Total & 409 & 380 & 286 & 415 & 419 \\
\hline
\end{tabular}

incorporation of residue was possible with the no tillage treatment and the in and on treatments were the same at the 0.0 rate of residue, hence the incomplete factorial design.

Soil disturbance and residue placement characteristics of the selected tillage operations were separated by tilling before or after residues were returned. In the former, the soil was disturbed, but residue was not incorporated. In the latter case, soil disturbance and residue incorporation were as would normally be expected with the tillage operation.

Primary tillage or chemical application (no tillage) occurred about 22 April of the fallow year. Secondary tillage for the plow and disk treatments was done as would normally occur in these fallow methods. However, to eliminate variable weed populations from influencing the results, weeds were controlled in all treatments by an application of atrazine (2-chloro-4-[ethylamino]-6-isopropylamino-1,3,5-triazine) at $0.80 \mathrm{~kg} \mathrm{ha}^{-1}$ and repeated applications of glyphosate ( $N$-[phosphonomethyl] glycine) at $0.84 \mathrm{~kg} \mathrm{ha}^{-1}$. Timing and type of secondary tillage operations for the plow and disk treatments (field cultivator [with sweep shovels], V-blade, and rod weeder) were determined by tillage requirements of nearby fallow areas that were not treated with herbicides. No tillage operations were used in the no tillage treatments.

Residue cover was measured using a point frame (Cook and Stubbendieck, 1986) and recorded as a decimal fraction of number of points contacting residue compared with the total number of points evaluated (300 per experimental unit). Winter wheat, 'Centurk 78 ', was seeded about 20 September in $300-\mathrm{mm}$ rows at a seeding rate of 225 seeds $\mathrm{m}^{-2}$. 
Table 3. Fraction soil cover of various tillage, residue amount, and residue placement treatments at planting.

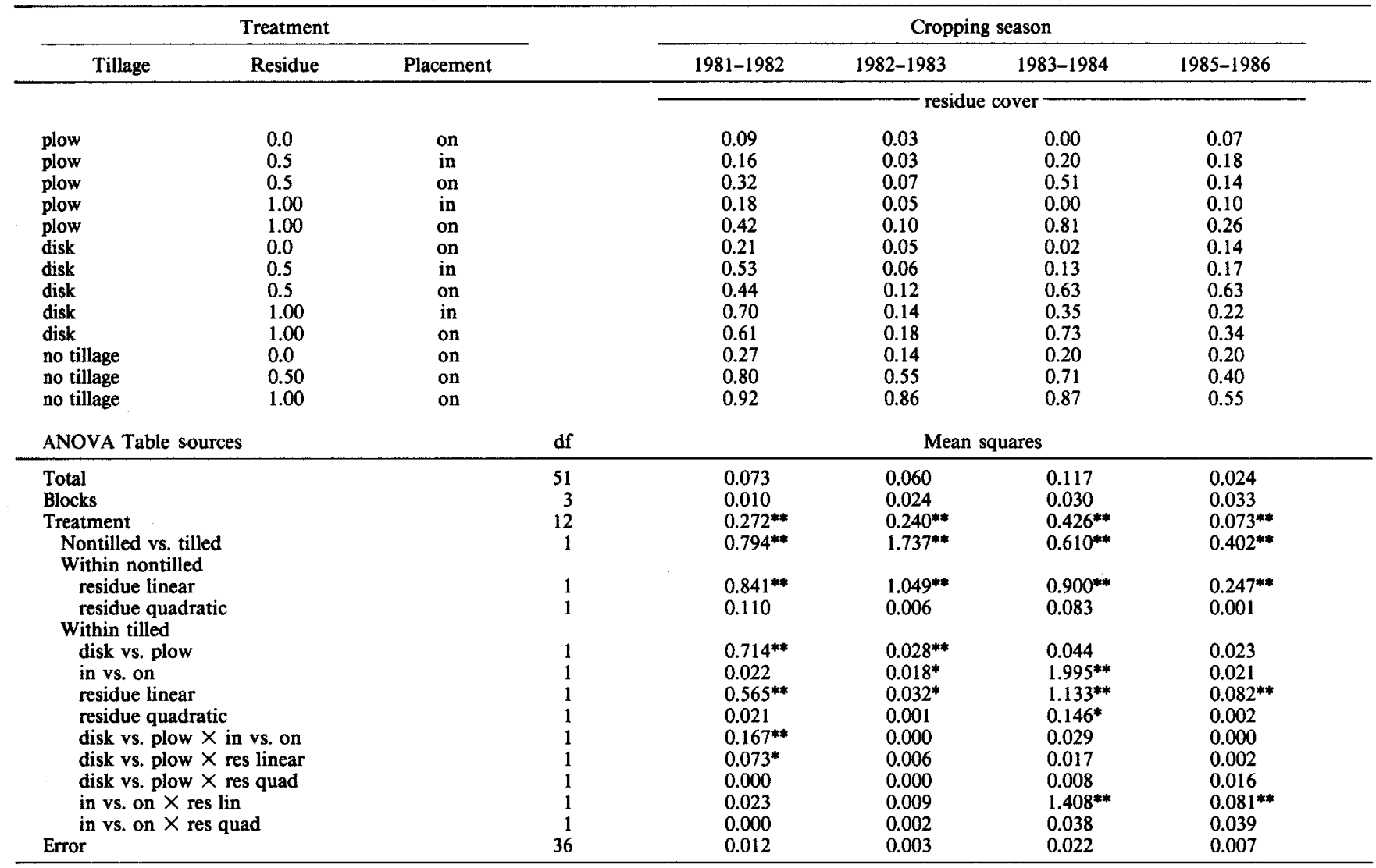

*,** Significant difference at the 5 and $1 \%$ probability level, respectively, by $F$-test.

Maximum-minimum thermometers were installed in the planted row in two replications to determine $50-\mathrm{mm}$ soil temperature. Biweekly mean maximum and minimum soil temperatures were calculated as the arithmetic mean of the maximum and minimum temperature recorded at approximately 0900 three times per week. Range of thermometers used was 0 to $50^{\circ} \mathrm{C}$. This resulted in some minimum temperatures being recorded as $0^{\circ} \mathrm{C}$ when the actual minimum temperature may have been less.

Soil water content was determined using the neutron scatter technique. Aluminum access tubes were installed in the seeded row at planting in all plots. Volumetric soil water determinations were made at seeding, periodically during the growth period, and at maturity during the 1981-1982 (0 to $1.2 \mathrm{~m}$ ) and $1982-1983(0$ to $1.8 \mathrm{~m})$ cropping seasons. Counts were made at $300-\mathrm{mm}$ depth intervals. Total soil water in the profile was obtained by summing the water content from all increments.

Dry-matter production was determined by harvesting all aboveground plant parts from a $0.91-\mathrm{m}^{2}$ area at intervals during crop development. Harvested samples were oven dried at $85^{\circ} \mathrm{C}$ to a constant weight and dry-matter production calculated. Leaf area index (LAI) was determined at anthesis from 50-culm subsamples. All green leaf blades were removed from each culm and passed through a leaf area meter (LI-COR LI3000) ${ }^{1}$. The LAI was calculated after determining the leaf dry-weight fraction and the specific leaf weight. Phenological stage was determined according to Feekes scale (Large, 1954) at approximately monthly intervals during the 1981-1982 and 1982-1983 cropping seasons.

At grain harvest of the 1981-1982 and 1982-1983 crops, plant material was sampled from a $0.91-\mathrm{m}^{2}$ area to determine

\footnotetext{
'Mention of commercial product does not imply endorsement by the USDA or the Univ. of Nebraska-Lincoln.
}

total dry-matter production, grain yield, tillers $\mathrm{m}^{-2}$, and heads $\mathrm{m}^{-2}$. The average number of kernels per head was determined from 20 randomly selected heads; kernel weight was determined from 500 kernels sampled randomly from the grain produced on each plot. The 1983-1984 and 19851986 crops harvested with a plot combine $\left(6.69 \mathrm{~m}^{2}\right)$. Yield component data were not collected on these crops.

Collected data were examined with analyses of variance. The incomplete nature of the experiment prevented use of standard comparisons for a factorial design. Therefore, single df comparisons were used to determine significance of treatment effects and their interactions (Table 1).

\section{RESULTS AND DISCUSSION}

Precipitation during the 1981-1982 and 1985-1986 cropping seasons (September through July) was near normal (419 mm; Table 2). Rainfall during the 19821983 crop year totaled $380 \mathrm{~mm}, 39 \mathrm{~mm}$ below normal, but with good distribution from April to June. The 1983-1984 season was the driest encountered during the study with total precipitation of $286 \mathrm{~mm}, 32 \%$ below normal. Rainfall during May and June was particularly low in comparison with other seasons and normal values. The study was established for the 1984-1985 season; however, hail on 27 May 1985 severely damaged the crop. Data from this season were not included in this report.

\section{Residue Cover}

Tillage and residue management practices influence many aspects of the soil environment. Data on residue cover (Table 3) were collected at planting in 19811982, 1982-1983, 1983-1984, and 1985-1986. In all 
cases tilled treatments had less residue cover than nontilled treatments. The amount of residue cover remained linearly related to amount of application throughout the study. In 1981-1982 no differences among residue placement treatments were observed. This may have been a result of secondary tillage operations during the fallow period incorporating residue in the on treatments and exposing residue in the in treatments, differential decomposition of residue among treatments, or both.

Generally, treatments did not interact; however, during 1981-1982, the plow treatment with incorporated residue had less residue on the soil surface at planting (averaged over rates, 0.17 ) than the on treatment $(0.37)$, compared with the disk treatment that had 0.62 cover with incorporated residue and only 0.53 with the on treatment. Again, this was a result of interaction of secondary tillage operations with primary tillage treatments. Residue placement by residue rate interaction was significant during both the 19831984 and 1985-1986 seasons.

\section{Soil Temperature}

Mean maximum soil temperatures from September through July during the 1981-1982 crop season in nontilled treatments, when averaged across residue rates and placement, were $3^{\circ} \mathrm{C}$ less than in tilled treatments (Fig. 1). In contrast, mean minimum soil temperatures for nontilled treatments were $1^{\circ} \mathrm{C}$ greater than that in tilled treatments. Disturbing topsoil caused more heat exchange to take place in the loosened layer according to van Duin (1956). As a result,

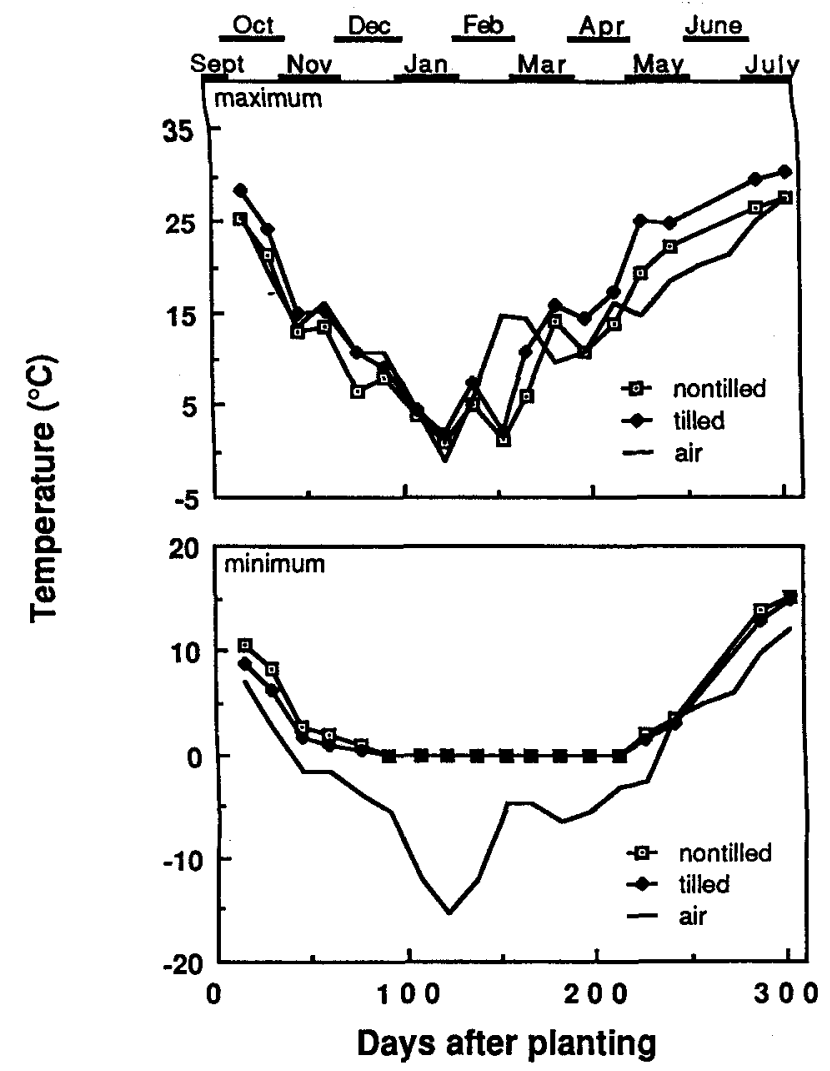

Fig. 1. Maximum and minimum soil (nontilled and tilled, $50 \mathrm{~mm}$ ) and air temperatures during the 1981-1982 cropping season. Minimum recording capability of thermometers was $0^{\circ} \mathrm{C}$. maximum soil temperature was greater on disturbed soil because of its reduced thermal conductivity.

Significant linear relationships existed among residue rates for maximum and minimum (Fig. 2) soil temperatures in nontilled treatments. Mean maximum soil temperatures under the zero residue rate treatment were consistently $3.5^{\circ} \mathrm{C}$ greater compared with those under the 1.0 rate from September to July in the 19811982 cropping season. Mean minimum soil temperatures under zero residue rate treatment were $1.5^{\circ} \mathrm{C}$ less than mean minimum temperatures under the1.0 residue treatment for the same period. Greater reflectivity and reduced thermal conductivity of the residue

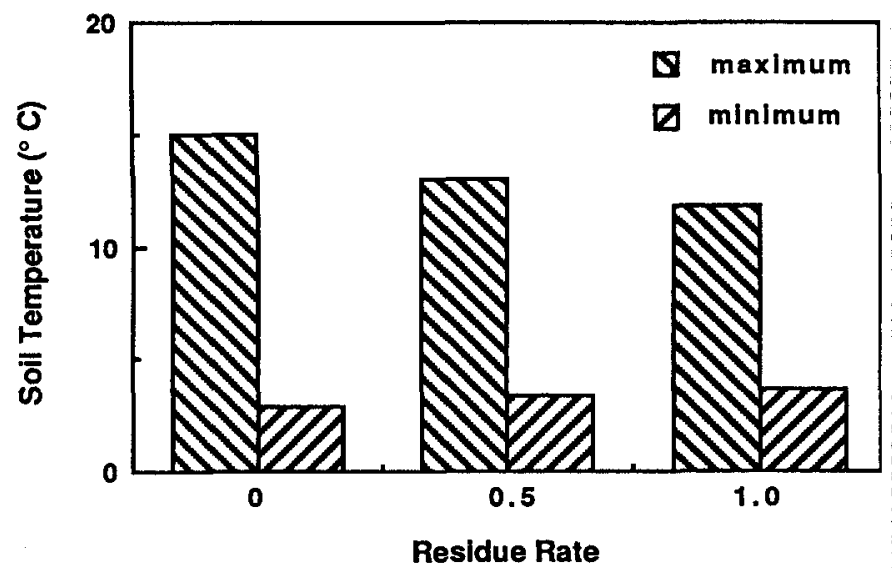

Fig. 2. Seasonal mean maximum and minimum soil temperature $(50 \mathrm{~mm})$ for three rates of residue in nontilled treatments during 1981-1982 cropping season. Significant linear component of variance for both maximum $(P<0.01)$ and minimum $(P<0.05)$ soil temperatures.

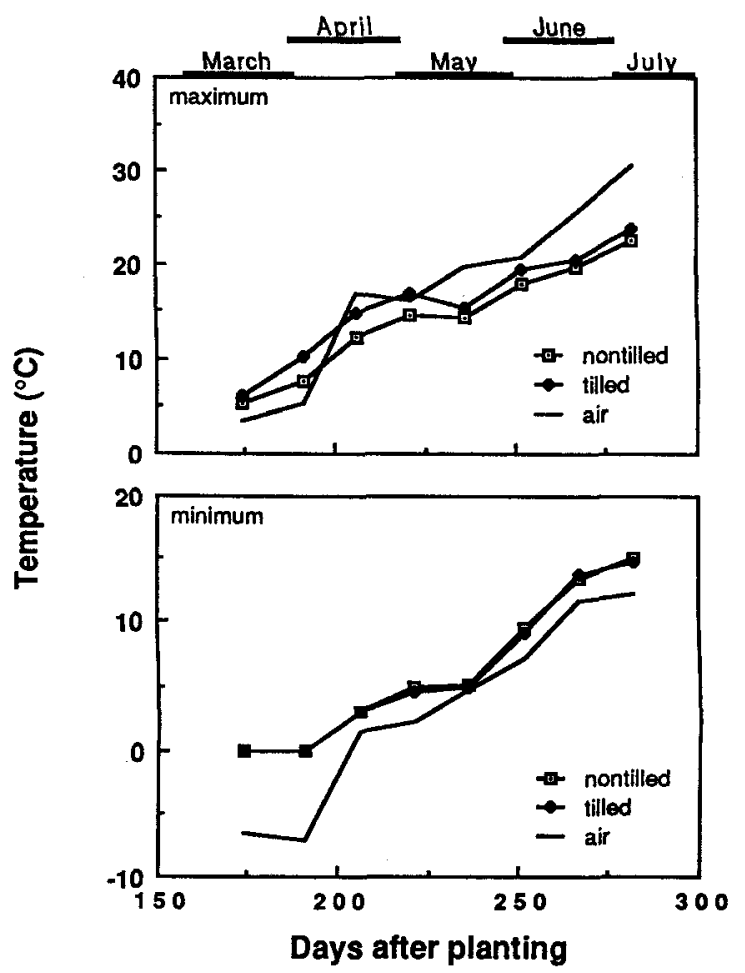

Fig. 3. Maximum and minimum soil (nontilled and tilled, $50 \mathrm{~mm}$ ), and air temperatures during the 1982-1983 cropping season. Minimum recording capability of thermometers was $0^{\circ} \mathrm{C}$. 
compared with soil resulted in less energy entering and leaving the residue-covered soil. These factors produce the greater maximum and lesser minimum temperatures for the bare soil reported here and in other research (Burrows and Larson, 1962; Wilhelm et al., 1986).

In general, residue placement did not significantly influence soil temperature. Significant differences between in and on treatments occurred only three times for maximum soil temperature and then differences were $<1^{\circ} \mathrm{C}$. Also, a significant interaction between tillage and residue placement was found for maximum soil temperature during the 1981-1982 season; however, the magnitude of the difference as again $<1^{\circ} \mathrm{C}$ and of little practical importance.

$1981-82$
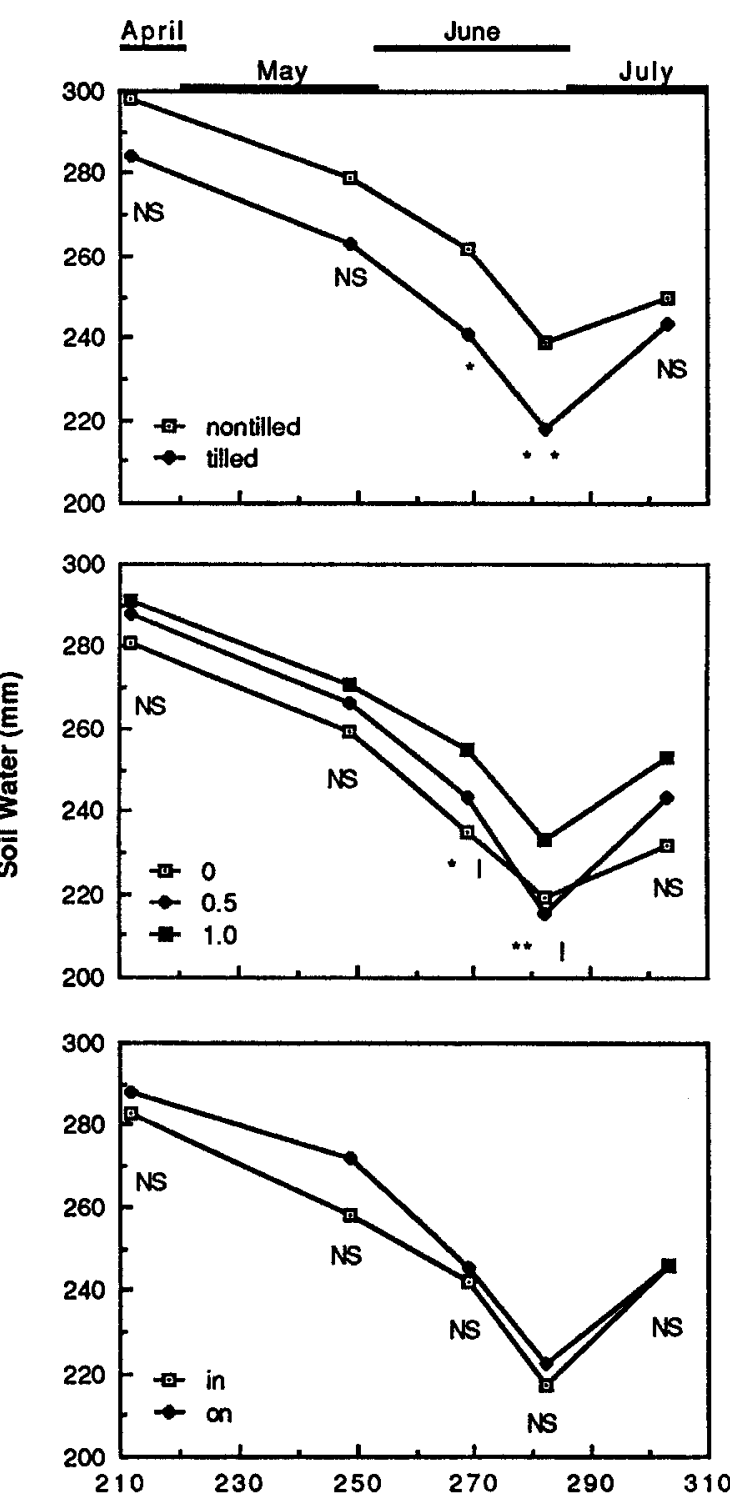

During the 1982-1983 cropping season, soil temperatures were collected only from March through July. Significant differences were found in maximum soil temperature, following patterns similar to those established during the 1981-1982 cropping season (Fig. 3). Minimum soil temperatures only differed between tilled and nontilled treatments, and then only from mid March through mid April.

\section{Soil Water}

Mean soil water content in the top $1.2 \mathrm{~m}$ (1981$1982)$ and $1.8 \mathrm{~m}$ (1982-1983) of soil, when averaged over residue rates and placements, differed significantly between tilled and nontilled treatments (Fig. 4). Nontilled treatments accumulated more water than
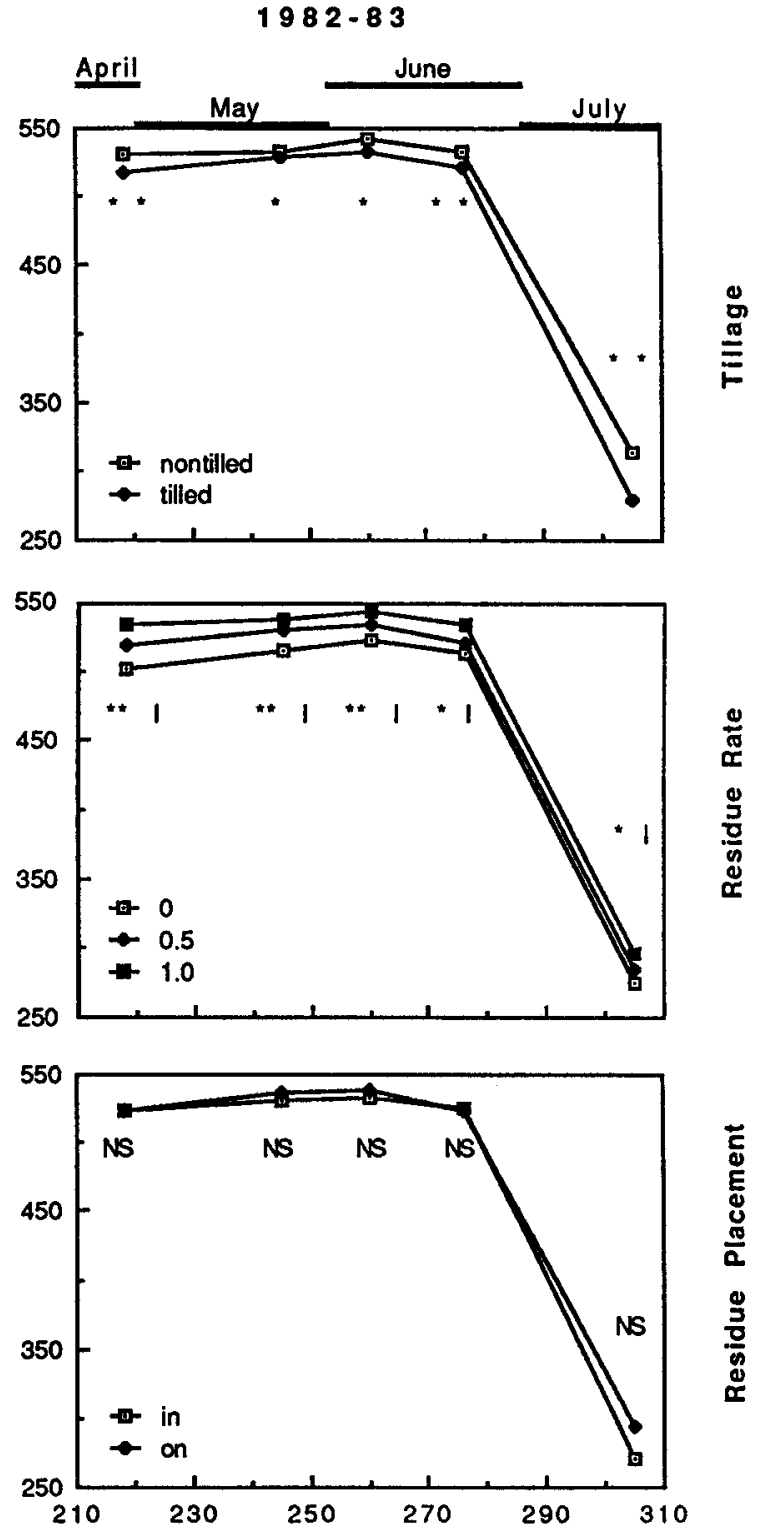

Days atter Planting

Fig. 4. Effect of tillage, residue rate, and residue placement on soil water content during the 1981-1982 (0 to $1.2 \mathrm{~m})$ and $1982-1983(0$ to $1.8 \mathrm{~m}$ ) cropping season. Significantly different means are indicated by ${ }^{*},{ }^{* *}$, and NS for the $5 \%$, and $1 \%$ levels, and not significantly different, respectively. Letter 1 refers to the linear component of variation. 


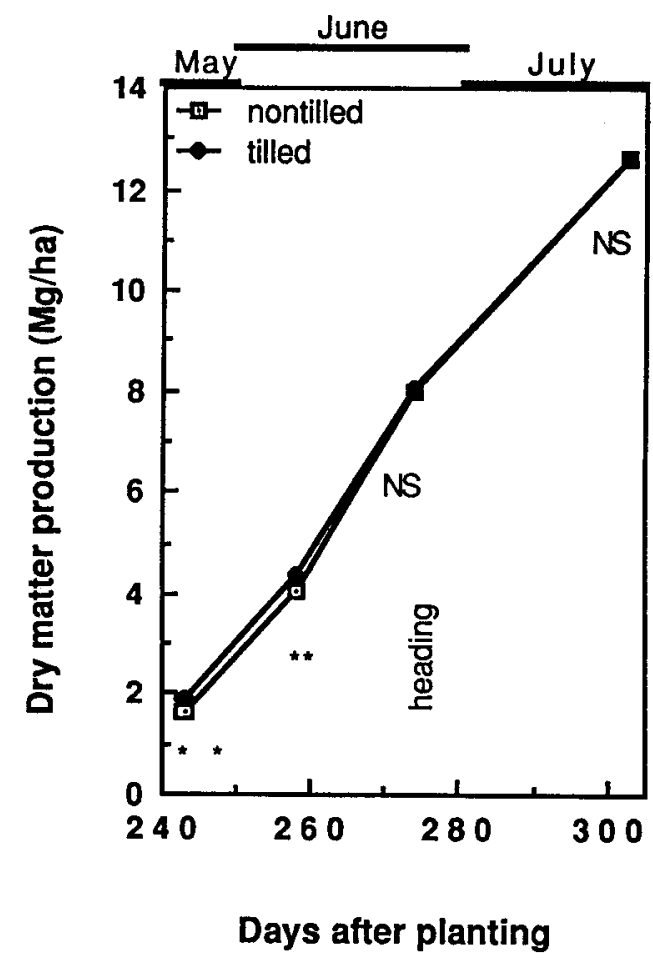

Fig. 5. Dry-matter production for winter wheat grown with and without tillage during the 1982-1983 cropping season. Significantly different means are indicated by ** and NS for the $1 \%$ level and not significantly different, respectively.

tilled treatments by an average of $20 \mathrm{~mm}$ water in both crop seasons.

Significant linear relationships existed among residue rates in nontilled treatments in both crop years. The 1.0 residue rate treatment resulted in 30 and 33 $\mathrm{mm}$ more water being stored during the 1981-1982 and 1982-1983 cropping seasons, respectively, compared with the zero treatment (Fig. 4). Among tilled treatments, a significant linear relationship also existed among surface residue rates; 1.0 residue rates accumulated an average of $29 \mathrm{~mm}$ more water during 1982-1983 crop year than did bare treatments. No significant differences were found among tilled treatments in 1981-1982 crop year for soil water content.

\section{Wheat Growth and Yield}

Early spring growth was slower with nontilled than other treatments during 1982-1983 cropping season. Mean dry-matter production averaged over residue rates was 1.64 and $4.04 \mathrm{Mg} \mathrm{ha}^{-1}$ in nontilled, and 1.86 and $4.39 \mathrm{Mg} \mathrm{ha}^{-1}$ in tilled treatments on the 23 May and 7 June samplings, respectively $(P<0.01)$; however, by completion of heading, these differences had disappeared (Fig. 5). A significant linear response of dry matter production of nontilled treatments to residue rate was also observed during the 1982-1983 season.

No significant differences were apparent in phenological development stage between different treatments in the 1981-1982 cropping season when development stages were evaluated at about monthly intervals. However in 1982-1983, with more frequent
Table 4. Effect of soil disturbance on wheat development stage (1982 to 1983 ).

\begin{tabular}{lccc}
\hline Sampling date & Nontilled & Tilled $\dagger$ & $\begin{array}{c}\text { Coefficient } \\
\text { of variation }\end{array}$ \\
\hline & mean phenological stage & & $(\%)$ \\
23 May & 5.6 & $6.0^{* *}$ & 3.8 \\
7 June & 9.7 & $10.0^{* *}$ & 2.9 \\
23 June & 10.5 & $10.5 \mathrm{NS}$ & $0.0 \S$ \\
\hline
\end{tabular}

**, NS Significant difference at $1 \%$ probability level and not significant, respectively, by analysis of variance.

$\dagger$ Mean of plow and disk treatments.

$\ddagger$ According to Feekes scale (Large, 1954).

$\S$ Number rounded to zero.

Table 5. Effect of surface residue (on) on wheat development stage, within nontilled soil (no tillage).

\begin{tabular}{|c|c|c|c|c|}
\hline \multirow[b]{2}{*}{ Sampling date } & \multicolumn{3}{|c|}{ Residue rates } & \multirow{2}{*}{$\begin{array}{l}\text { Coefficient } \\
\text { of variation }\end{array}$} \\
\hline & 0 & 0.5 & 1.0 & \\
\hline & \multicolumn{3}{|c|}{ mean phenological stage $\dagger-$} & (\%) \\
\hline $\begin{array}{l}23 \text { May } \\
7 \text { June } \\
23 \text { June }\end{array}$ & $\begin{array}{r}6.0 \\
10.0 \\
10.5\end{array}$ & $\begin{array}{r}6.0 \\
9.5 \\
10.5\end{array}$ & $\begin{array}{l}5.3 \mathrm{1}^{* *} \\
9.6 \mathrm{q}^{*} \\
10.5 \mathrm{NS}\end{array}$ & $\begin{array}{l}3.8 \\
2.9 \\
0.0 \neq\end{array}$ \\
\hline \multicolumn{5}{|c|}{$\begin{array}{l}*, * * \text { Significant difference at } 5 \text { and } 1 \% \text { probability level, respectively, by anal- } \\
\text { ysis of variance. Letters } 1 \text { and q refer to the linear and quadratic components } \\
\text { of variation, respectively. } \\
\text { NS = Not significant. } \\
\dagger \text { According to Feekes scale (Large, } 1954) \text {. } \\
\ddagger \text { Number rounded to zero. }\end{array}$} \\
\hline
\end{tabular}

evaluation of developmental stage, phenological development stage differed significantly between nontilled and tilled treatments (Table 4), and was linearly associated with residue rate in nontilled treatments (Table 5). Wheat plants grown without tillage were at Stages 5 and 9, while those in plow treatments were at Stages 6 and 10 on 23 May and 7 June, respectively. Reduced soil temperatures of treatments with less soil disturbance or more residue cover may have slowed development when meristems were near the soil surface. However, when culm elongation elevated meristems above the soil, development was influenced to a greater extent by air temperature and daylength (assumed constant over all treatments). By 23 June all treatments were at the Feekes Stage 10.5.

Tillage practice significantly affected LAI during the 1982-1983 and 1983-1984 seasons, when nontilled treatments had significantly reduced LAI (Table 6). A linear relationship was found among residue rates in nontilled treatments and among surface residue rates in tillage treatments for LAI as well. The reduced LAI of the nontilled and mulched treatments support the conclusion that reduced soil temperature in these treatments reduced phenological development during the vegetative stage. Klepper et al. (1982) have shown that leaf appearance is related to accumulation of heat units. If meristem temperature is defined by soil temperature during vegetative development from the start of soil temperature data collection (15 March; near the time when average soil temperature rises above $0^{\circ} \mathrm{C}$ ) through jointing (15 May), the difference in heat unit accumulation between tilled and nontilled treatments was $50^{\circ} \mathrm{C} \mathrm{d}$ (base $0^{\circ} \mathrm{C}$ ). A phyllochron of $117^{\circ} \mathrm{C} \mathrm{d}$ for a 15 October emergence and $41^{\circ} 14^{\prime}$ latitude was calculated from the algorithm of Baker et al. (1980). This difference translates into 0.43 leaves on each culm. No 
Table 6. Effect of surface residue on leaf area index (at anthesis) of winter wheat in nontilled (no tillage) and tilled (disk and plow) treatments during the 1982-1983 cropping season.

\begin{tabular}{lccc}
\hline & \multicolumn{3}{c}{ Leaf area index $\dagger$} \\
\cline { 2 - 4 } Residue rate & Nontilled & Tilled $\ddagger$ & Mean \\
\hline 0 & 1.10 & 1.20 & \\
0.5 & 0.90 & 0.90 & \\
1.0 & 0.90 & 0.95 & \\
Significance & $1^{* *}$ & $1^{* *}$ & \\
Mean & 1.00 & 1.08 & $1.04^{*}$ \\
\hline
\end{tabular}

*** Significant difference at $5 \%$ and $1 \%$ levels of probability, respectively, by analysis of variance. Letter 1 refers to the linear component of variation. + Coefficient of variation is $9.9 \%$.

$¥$ Mean of plow and disk treatments.

calculation can be made about the size of leaves, but there should be 0.43 more leaves on culms in tilled treatments than nontilled treatments. This could easily represent the difference in LAI found in this study.

In the 1981-1982, 1982-1983, and 1985-1986 cropping seasons, we found no significant differences in grain yield between tilled and nontilled treatments; however, significant differences were observed during 1983-1984 (3.48 vs. $3.20 \mathrm{Mg} \mathrm{ha}^{-1}$, respectively). The lack of a significant response during 1981-1982 and 1982-1983 is surprising because we noted a greater amount of water stored with no tillage throughout the season (Fig. 4). The pattern of soil water distribution in the $1.80-\mathrm{m}$ soil depth (per $0.3-\mathrm{m}$ soil layer) during the April and July 1983 samplings was investigated (Fig. 6). In April significant differences occurred between tilled and nontilled treatments in the top 0.3$\mathrm{m}$ soil layer and in that layer below $1.5 \mathrm{~m}$. By the end of the season most of the additional water with the nontilled treatments was below $1.5 \mathrm{~m}$. Low rooting density or root restrictions caused by tillage pans (Wilhelm et al., 1982) may have limited the plants' ability to extract this water. This may explain why we did not observe an increase in grain yield under nontilled system. Fenster and Peterson (1979) reported that during only one year of a long-term study (1966-1977) did nontilled treatments produce a greater $(P<0.05)$ amount of grain that plowed treatments under the same environment. Although detailed soil water measurements were not collected during the 1983-1984 season, the very low rainfall (Table 2) combined with unusually low residue cover at planting (Table 3 ) may have contributed to the lower yield for nontilled treatments.

Examination of the yield components showed that,

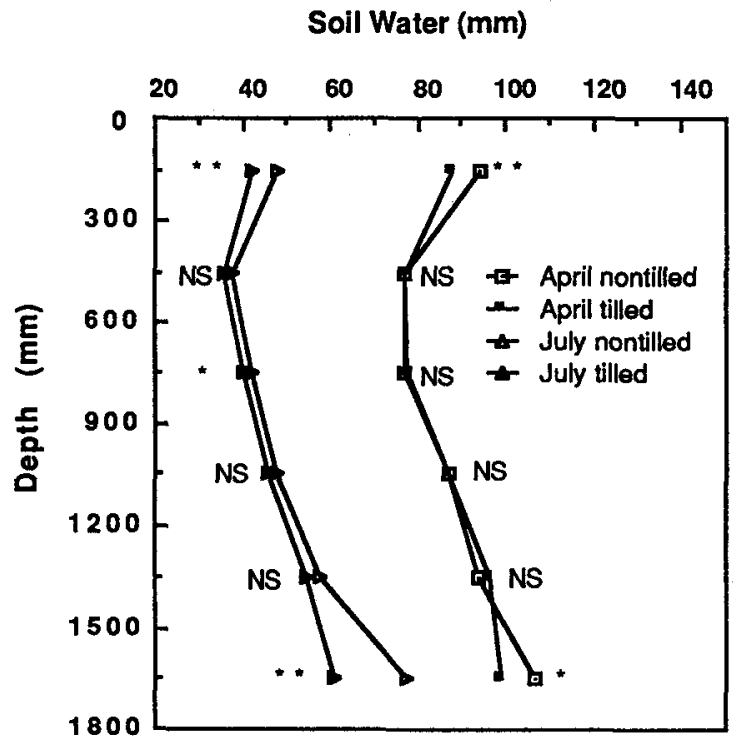

Fig. 6. Soil water content with depth for nontilled and tilled (mean of plow and disk) treatments in April and July during the 19821983 cropping season. Significantly different means are indicated by ${ }^{*},{ }^{* *}$, and NS for the $5 \%$ and $1 \%$ levels, and not significantly different, respectively.

in the 1981-1982 cropping season, there was a significant effect of tillage on tillers $\mathrm{m}^{-2}$, heads $\mathrm{m}^{-2}$, and kernel weight when averaged across residue rates $(\mathrm{Ta}-$ ble 7). Nontilled treatments had more tillers and heads $\mathrm{m}^{-2}$, and lower kernel weight than tilled treatments. In contrast, during the 1982-1983 no significant differences were found in tiller and head density between tilled and nontilled treatments. However, in each case the numerical value for the nontilled treatment was greater than that of the tilled treatment. Bartholomew et al. (1977) found that no tillage increased final tiller density over that of plowing in three of four environments. Similar results were found by Ellis et al. (1979) in that no tillage increased the number of ears $\mathrm{m}^{-2}$. Black (1970) reported that soil water and temperature conditions near the plant crown during spring were extremely important in the formation of adventitious roots and tillers. Smika and Ellis (1971) found that soil temperatures below $10^{\circ} \mathrm{C}$ reduced wheat tillering capacity. In our conditions, mean soil temperatures during the tillering period (April) of both years were approximately 6 and $8^{\circ} \mathrm{C}$ for nontilled and tilled treatments, respectively. It appears that soil temperature

Table 7. Effect of soil disturbance on grain yield and yield components of winter wheat during the 1981-1982 and 1982-1983 cropping seasons, and yield during the 1983-1984 and 1985-1986 cropping seasons.

\begin{tabular}{|c|c|c|c|c|c|c|c|c|c|c|c|c|}
\hline \multirow[b]{2}{*}{ Yield component } & \multicolumn{3}{|c|}{$1981-1982$} & \multicolumn{3}{|c|}{$1982-1983$} & \multicolumn{3}{|c|}{ 1983-1984 } & \multicolumn{3}{|c|}{$1985-1986$} \\
\hline & Nontilled & Tilled $†$ & $\mathrm{CV}$ & Nontilled & Tilled & $\mathrm{CV}$ & Nontilled & Tilled & $\mathrm{CV}$ & Nontilled & Tilled & $\mathrm{CV}$ \\
\hline & & & $(\%)$ & & & $(\%)$ & & & (\%) & & & (\%) \\
\hline \multicolumn{13}{|l|}{ Grain yield } \\
\hline$\left(\mathrm{Mg} \mathrm{ha}^{-1}\right)$ & 3.02 & $2.92 \mathrm{NS}$ & 8.8 & 4.26 & 4.17 NS & 11.3 & 3.20 & $3.48^{*}$ & 8.2 & 4.05 & $3.8 \mathrm{NS}$ & 7.5 \\
\hline Tillers $\mathrm{m}^{-2}$ & 652 & $574^{* * *}$ & 5.6 & 602 & $596 \mathrm{NS}$ & 9.3 & & & & & & \\
\hline Heads $\mathrm{m}^{-2}$ & 641 & $561^{* *}$ & 5.7 & 594 & $489 \mathrm{NS}$ & 9.6 & & & & & & \\
\hline \multicolumn{13}{|l|}{ Kernel weight } \\
\hline (mg kernel ${ }^{-1}$ ) & 26.0 & $27.0^{*}$ & 5.9 & 32.5 & $31.8^{* *}$ & 2.3 & & & & & & \\
\hline Kernels head ${ }^{-1}$ & 22.7 & $23.2 \mathrm{NS}$ & 4.3 & 22.3 & $22.5 \mathrm{NS}$ & 7.2 & & & & & & \\
\hline
\end{tabular}

,**: Significant difference at 5 and $1 \%$ levels of probability, respectively, by analysis of variance.

NS $=$ Not significant

$\uparrow$ Mean of plow and disk treatments. 
under both conditions could have affected tillering, with the nontilled treatments being affected to a greater extent. The differences in kernel weight between the two seasons probably reflects compensation for differences in head density.

\section{CONCLUSIONS}

In this study depressed maximum soil temperature (50-mm depth) and increased soil water were associated with nontilled and mulched treatments. Winter wheat grain yield was not influenced by either residue management or soil disturbance, except during the 1983-1984 season when tilled treatments produced more grain than the nontilled treatment. The yield components (tiller and head number, and kernel weight) varied in their response to soil disturbance and residue management over years.

Rate of development and dry matter yield was reduced prior to anthesis for winter wheat grown without tillage or with the 1.0 surface residue rate. These conditions (no tillage and surface residues) were also associated with greater amounts of available soil water through the growing season, even at maturity. Greater availability of water in arid climates is normally associated with greater yield (Unger and McCalla, 1980). However, nontilled systems frequently do not result in greater yield than tilled systems (Unger, 1977; Ellis et al., 1979). The interaction of wheat development with soil temperature, air temperature, and daylength may contribute to the crop's inability to capitalize on the greater amount of water stored in nontilled systems.

\section{REFERENCES}

Adams, J.E. 1965. Effect of mulches on soil temperature and grain sorghum development. Agron. J. 57:471-474.

1966. Influences of mulches on runoff, erosion and soil moisture depletion. Soil Sci. Soc. Am. Proc. 30:110-114.

G.F. Arkin, and J.T. Ritchie. 1976. Influences of row spacing and straw mulch on first stage drying. Soil Sci. Soc. Am. J. 40:436442.

Allmaras, R.R., W.C. Burrows, and W.E. Larson. 1964. Early growth of corn as affected by soil temperature. Soil Sci. Soc. Am. Proc. 28:271-275.

Anderson, D.T., and G.C. Russell. 1964. Effects of various quantities of straw mulch on the growth and yield of spring and winter wheat. Can. J. Soil Sci. 44:109-118.

Army, T.J., A.F. Wiese, and R.J. Hanks. 1961. Effect of tillage and chemical weed control practices on soil moisture losses during the fallow period. Soil Sci. Soc. Am. Proc. 25:410-413.

Baker, C.K., J.N. Gallagher, and J.L. Monteith. 1980. Daylength and leaf appearance in winter wheat. Plant, Cell, Environ. 3:285287.

Bartholomew, P.W., D.M.B. Chestnutt, and J.G. Stuart. 1977. A comparison of the effect of direct drilling and sowing after conventional cultivation on yields of cereals in Northern Ireland. Rec. Agric. Res. 25:89-94.

Black, A.L. 1970. Soil water and soil temperature influences on dryland winter wheat. Agron. J. 62:797-801.

Burns, R.L., D.J. Cook, and R.E. Phillips. 1971. Influence of no tillage on soil moisture. Agron. J. 73:593-596.

Burrows, W.C., and W.E. Larson. 1962. Effect of amount of mulch on soil temperature and early growth of corn. Agron. J. 54:1922.

Ciha, A.J. 1982. Yield and yield components of four spring wheat cultivars grown under three tillage systems. Agron. J. 74:31 7-320.

Cook, C.W., and J. Stubbendieck. 1986. Range research: Basic problems and techniques. Soc. Range Sci., Denver, CO.

Duley, F.L. 1960. Yields in different cropping system and fertilizer tests under stubble mulching and plow in Eastern Nebraska. Nebraska Agric. Exp. Stn. Res. Bull. 190.

Ellis, E.B., J.G. Elliot, F. Pollard, R.O. Cannell, and B.T. Barnes. 1979. Comparison of direct drilling, reduced cultivation and ploughing on the growth of cereals. J. Agric. Sci. 93:391-401.

Fenster, C.R., and G.A. Peterson. 1979. Effects of no tillage fallow as compared to conventional tillage in a wheat fallow rotation. Nebraska Agric. Exp. Stn. Res. Bull. 259.

Greb, B.W. 1966. Effect of surface-applied wheat straw on soil water losses by solar distillation. Soil Sci. Soc. Am. Proc. 30:786-788.

Hillel, D.I., C.H. Bavel, and H. Talpaz. 1975. Dynamic simulation of water storage in fallow soil as affected by mulch of hydrophobic aggregates. Soil Sci. Soc. Am. Proc. 39:826-833.

Klepper, B., R.W. Rickman, and C.M. Peterson. 1982. Quantitative characterization of vegetative development in small cereal grains. Agron. J. 74:789-792.

Large, E.C. 1954. Growth stages in cereals: Illustration of the Feekes scale. Plant Pathol. 3:128-129.

McCalla, T.M., and T.J. Army. 1964. Stubble mulch farming. Adv. Agron. 13:125-163.

Papendick, R.I., M.J. Lindstrom, and V.L. Cochran. 1973. Soil mulch effect on seedbed temperature and water during fallow in eastern Washington. Soil Sci. Soc. Am. Proc. 37:307-314.

Smika, D.E., and R. Ellis. 1971. Soil temperature and wheat straw mulch effects on wheat plant development and nutrient concentration. Agron. J. 63:388-391.

Unger, P.W. 1977. Tillage effect on winter wheat production where the irrigated and dryland crops are alternated. Agron. J. 69:944950.

, and T.M. McCalla. 1980. Conservation tillage systems. Adv. Agron. 33:1-58.

van Duin, R.H.A. 1956. On the influence of tillage on conduction of heat, diffusion of air and infiltration of water in soil. Versl. Landbouwkd. Onderz. 62:1-74.

Wilhelm, W.W., J.W. Doran, and J.F. Power. 1986. Corn and soybean yield response to crop residue management under no tillage production systems. Agron. J. 78:184-189.

, L.N. Mielke, and C.R. Fenster. 1982. Root development of winter wheat as related to tillage practice in western Nebraska. Agron. J. 74:85-88. 